\title{
Cryptosporidium infection in ostriches (Struthio camelus) in Brazil: Clinical, Morphological and Molecular Studies
}

Author(s)

Santos MMAB

Peiró JR

Meireles $\mathrm{MV}^{*}$

Departmento de Clínica, Cirurgia e Reprodução Animal

Universidade do Estado de São Paulo - UNESP

- Campus de Araçatuba.

\section{Mail Address}

Marcelo Vasconcelos Meireles

Rua Clóvis Pestana, 793

Bairro Dona Amélia

16.050-680. Araçatuba, SP, Brasil

Tel.: +55 1836363285

Fax: +551836244542

E-mail: marcelo@fmva.unesp.br

\section{Keywords}

Clinical signs, Cryptosporidium, morphology, ostriches, PCR-RFLP.
Financial support: Fundação para o Desenvolvimento da UNESP - FUNDUNESP, Grant No. 00645-03-DFP and Conselho Nacional de Desenvolvimento Científico e Tecnológico - CNPq (Scientific Initiation Scholarship to Santos, M.M.A.B.)
Arrived: january / 2005

Approved: april / 2005

\section{ABSTRACT}

Avian cryptosporidiosis has been reported in more than 30 species of birds. To date, the species infecting birds are C. baileyi, C. galli and C. meleagridis. In this study, the morphological, clinical and molecular characteristics of a Brazilian ostrich isolate of Cryptosporidium are described. The oocysts of this Brazilian isolate are larger and more elongated than those of Cryptosporidium previously reported in ostriches, which were morphologically similar to C. meleagridis. Morphological, biological and molecular analyses demonstrated similarity of this ostrich isolate with C. baileyi, suggesting that there are at least two Cryptosporidium species infecting ostriches; one with molecular, biological and morphological characteristics related to $C$. baileyi, and another morphologically similar to C. meleagridis.

\section{INTRODUCTION}

Protozoa of the genus Cryptosporidium are apicomplexan parasites that complete their biological cycle in the surface of epithelial cells of the digestive and respiratory systems of birds, fishes, mammals and reptiles (Xiao et al., 2004).

Avian cryptosporidiosis has been reported in more than 30 species of birds in many countries (Meireles \& Figueiredo, 1992, Morgan et al., 2001, Sréter \& Varga, 2000).

Currently, 14 species are officially recognized, C. andersoni, C. canis, C. felis, C. hominis, C. muris, C. parvum, C. suis and C. wrairi in mammals, C. baileyi, C. galli and C. meleagridis in birds, C. serpentis and C. saurophilum in reptiles and C. molnari in fish (Ryan et al. 2003; Ryan et al., 2004, Xiao et al., 2004).

C. baileyi inhabits the respiratory tract, bursa of Fabricius and cloaca of the domestic chicken and other birds (Current et al., 1986, Meireles \& Figueiredo, 1992, Meireles et al., 1999, Sréter \& Varga, 2000).

C. meleagridis has already been reported in humans (McLauchlin et al., 2000, Morgan et al., 2000, Pedraza-Dias et al., 2000, Guyot et al., 2001, Tiangtip \& Jongwutiwes, 2002, Alves et al., 2003, Cama et al., 2003, Gatei et al., 2003), but it is primarily a parasite of intestinal epithelial cells of birds, particularly turkeys (Slavin, 1955, Sréter \& Varga, 2000).

Besides $C$. baileyi and $C$. meleagridis, the proventricular epithelium of birds is infected by $C$. galli. The oocysts of this species measure $8.2 \times 6.3$ $\mu \mathrm{m}$ and have shape index (length/width) of 1.30. Natural hosts are finches (Spermestidae and Fringillidade), chickens (Gallus gallusf. talent.), Capercaille (Tetrao urogallus) and Pine grosbeak (Pinicola enucleator) (Ryan et al. ,2003).

The infection in ostriches may be subclinical (Gajadhar 1993) or associated to prolapse of phallus and cloaca (Allwright \& Wessels, 1993, Bezuidenhout et al., 1993, Penrith \& Burger, 1993, Penrith et al., 1994) and pancreatic necrosis (Jardine \& Verwoerd, 1997). 
Gajadhar (1994) carried out cross transmission studies and morphological analysis of oocysts of a Cryptosporidium isolate recovered from ostriches, and there was no cross transmission to suckling mice, chicken, turkey and Japanese quail. Morphological analysis showed that oocysts diverged morphologically from that of $C$. baileyi and were similar to oocysts of C. meleagridis, and suggested that the ostrich isolate might represent another species of Cryptosporidium from birds.

In this study, the morphological, clinical and molecular characteristics of a Brazilian ostrich isolate of Cryptosporidium are described.

\section{MATERIAL AND METHODS}

\section{Birds}

High mortality rates of unknown origin were recorded from seven to 30-days-old in ostriches raised at the facilities of the Veterinary Medicine Course of Universidade do Estado de São Paulo (UNESP), campus of Araçatuba, São Paulo, Brazil. Birds were thin and showed secondary bacterial infection sporadically, with yellow fatty liver and cloacal prolapse. From five birds which had cloacal prolapse, two were sent for necropsy and parasitological screening.

\section{Parasites}

Fresh harvested oocysts obtained from fecal samples of the examined birds were purified in discontinuous sucrose and cesium chloride gradients (Arrowood \& Donaldson, 1996) and stored in 2.5\% potassium dichromate at $+4 \mathrm{C}$.

\section{Morphological Analysis}

The size and morphology of the oocysts were determined by evaluating 100 oocysts using malachite green (Elliot et al., 1999) with an Olympus BX-45 microscope equipped with a calibrated ocular micrometer.

\section{Histopathology and Mucosal Smears}

Fragments of proventriculum, duodenum, jejunum, ileum, ceca, proximal, medium and distal rectum, coprodeum, urodeum and bursa of Fabricius were collected, routinely processed for histopathology and stained with hematoxylin and eosin. Mucosal smears of the same organs were stained by modified Kinyoun acid-fast staining.

\section{Genomic DNA extraction}

DNA was extracted with phenol-chlorophorm as previously described (Sréter et al., 2000) and purified using the Prep-A Gene DNA purification system (Bio$\left.\operatorname{Rad}^{\circledR}\right)$.

\section{Nested-PCR reaction}

Cryptosporidium species were identified by a nested-PCR/RFLP (Xiao et al., 1999). Ultra-pure autoclaved water and DNA of a bovine $C$. parvum isolate which had been previously identified by PCRRFLP were used as negative and positive controls, respectively.

\section{Restriction Fragment Length Polymorphism (RFLP)}

For RFLP analysis, $20 \mu \mathrm{l}$ of secondary PCR product were digested with a mixture containing $20 \mathrm{U}$ of restriction enzyme Sspl or Asel (New England Biolabs ${ }^{\circledR}$ ), and $5 \mu \mathrm{l}$ of restriction buffer at $37^{\circ} \mathrm{C}$ for $1 \mathrm{~h}$, as recommended by the supplier.

The products of PCR/RFLP were analyzed by electrophoresis on a $1.5 \%$ agarose gel, stained with ethidium bromide and visualized under ultraviolet light.

\section{RESULTS}

Oocysts of the ostrich isolate measured $6.0 \times 4.8$ $\mu \mathrm{m}$ (5.0-6.5 $\times 4.2-5.3)$ with a shape index (length/width) of $1.31(n=100)$ (Figure 1).

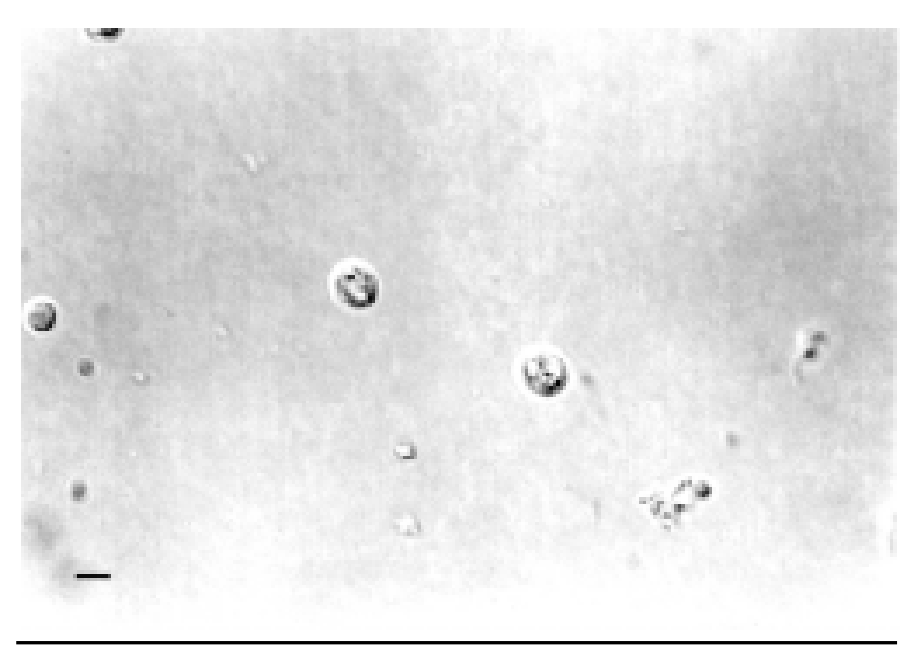

Figure 1 - Nomarski interference-contrast photomicrograph. Oocysts of Cryptosporidium sp. from ostriches. Scale bar is 5 $\mu \mathrm{m}$.

The two birds with cloacal prolapse examined by histological sections had developmental stages of cryptosporidium covering the border of cloacal epithelial cells. 
Mucosal smears of naturally infected ostriches showed developmental Cryptosporidium stages mainly in the distal rectum and coprodeum. Slight infection was observed at the mucosa of proximal and medium rectum, urodeum, and rarely in the ceca and bursa of Fabricius.

Histological sections revealed the parasite only in distal rectum, coprodeum, urodeum and rarely in the bursa of Fabricius. Microscopic lesions were seen mainly in coprodeum and urodeum as an infiltrate of monoand polymorphonuclear cells, epithelial hyperplasia, mucosal swelling and many ovoid parasites in the border of epithelial cells (Figures 2 and 3). There was necrosis and atrophy of the bursa of Fabricius in the absence of developmental stages of Cryptosporidium in the bursal epithelium.

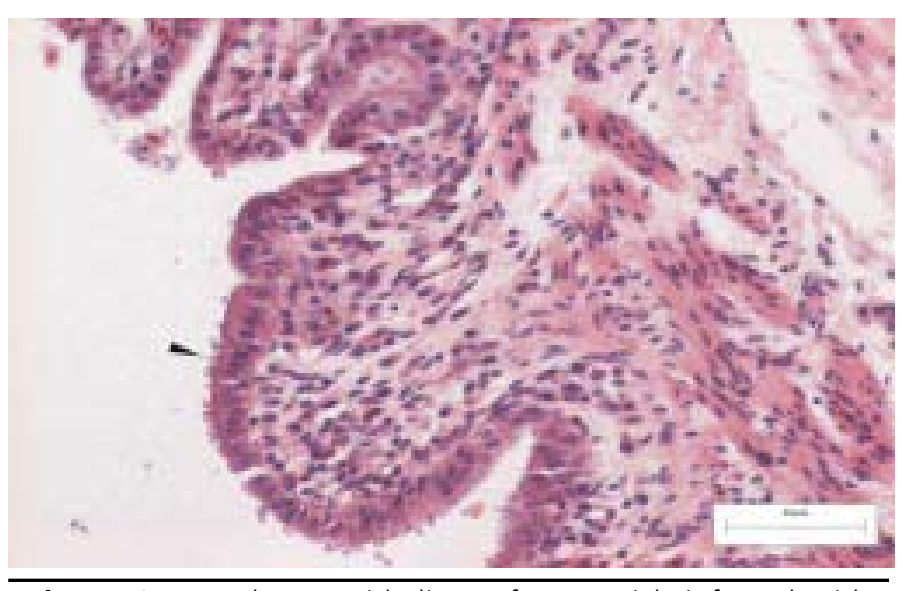

Figure 2 - Urodeum epithelium of an ostrich infected with Cryptosporidium sp. showing mononuclear cell infiltration in the submucosa and developmental stages of the parasite in the epithelial surface (arrowhead).

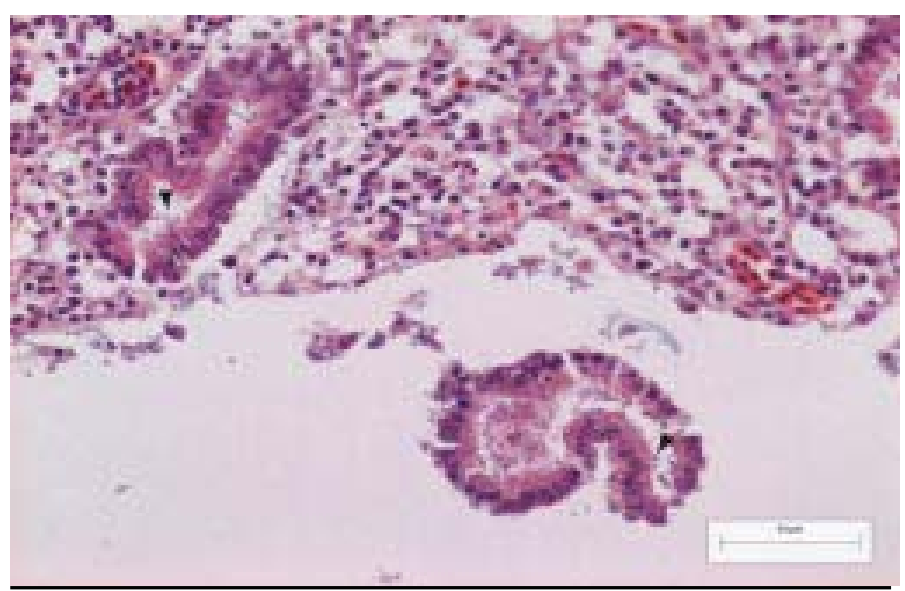

Figure 3 - Coprodeum epithelium of an ostrich infected with Cryptosporidium sp. showing severe infiltration of heterophils, macrophages, and mononuclear cells in the submucosa and developmental stages of the parasite in the epithelial surface (arrowhead).
Nested-PCR resulted in fragments of approximately $1,300 \mathrm{bp}$ and $830 \mathrm{bp}$ for primary and secondary reaction respectively. The digestion of the secondary product with enzymes Sspl and Asel yielded bands of approximately 250 and $570 \mathrm{bp}$ and 100 and $620 \mathrm{bp}$, respectively.

\section{DISCUSSION}

There were no evidences of relationships between ostrich mortality, bursal necrosis and Cryptosporidium infection. Stressing conditions leading to immunossupression or poor husbandry practices related to feed, water or hygiene apparently must have been present as predisposing factors to the onset of cloacal prolapse or other pathology related to the species of Cryptosporidium found in this experiment, since the improvement in husbandry practices has stopped the mortality and clinical signs, even in the presence of the parasite.

Oocysts of the Brazilian isolate are larger and more elongated than those of Cryptosporidium found in ostriches by Gajadhar (1993, 1994). The author described the presence of oocysts related to the occurrence of subclinical cryptosporidiosis in adult ostriches, but no description of the development site of the parasite in the birds was available. Oocysts were spherical to subspherical and measured $4.6 \times 4.0 \mathrm{~mm}$; shape index (length/width) 1.15.

C. baileyi oocysts have ovoid shape and measure $6.0 \times 4.6 \mu \mathrm{m}$; shape index 1.31 (Meireles \& Figueiredo, 1992) or $6.3 \times 5.2 \mu \mathrm{m}$; shape index 1.4 (Current et al., 1986), similar to the morphological data of the Brazilian ostrich isolate presented herein.

There is no information on which species of Cryptosporidium may infect ostriches. Probably the present ostrich isolate is the same species related to cloacal prolapse in other reports (Allwright \& Wessels, 1993, Penrith et al., 994, Jardine \& Verwoerd, 1997). Since the morphological data of the isolate described by Gajadhar (1994) are related to C. meleagridis, which are spherical and measure $5.2 \times 4.6 \mu \mathrm{m}$; shape index 1.13 (Lindsay et al., 1989), and not to C. baileyi, probably there are 2 Cryptosporidium species infecting ostriches, one with molecular, biological and morphological characteristics related to C. baileyi and a second one morphologically related to $C$. meleagridis.

It is possible to differentiate C. baileyi from $C$. meleagridis by visualization of the electrophoresis profile of digested bands of the secondary reaction product. Nevertheless, it is not possible to differentiate 
between species/genotypes with similar digestion profiles without sequencing the amplified fragments (Xiao et al., 1999).

Egyed et al., (2002) recommended that polyphasic typing must be accomplished for species not yet classified, with evaluation of biological characteristics, besides the molecular analysis of the parasite.

For a definitive classification of this isolate as $C$. baileyi or as a new species infecting ostriches, the comparison of the sequenced fragments would be necessary, followed by phylogenetic analysis. Besides, further studies involving its biological and morphological characteristics would also be necessary.

\section{REFERENCES}

Allwright DM, Wessels J. Cryptosporidium species in ostriches. The Veterinary Record 1993; 133:24

Alves MA, Xiao L, Sulaiman I, Lal AA, Matos O, Antunes F. Subgenotype analysis of Cryptosporidium isolates from humans, cattle, and zoo ruminants in Portugal. Journal of Clinical Microbiology 2003; 41:2744-2747

Arrowood MJ, Donaldson K. Improved purification methods for calf-derived Cryptosporidium parvum oocysts using discontinuous sucrose and cesium chloride gradients. Journal of Eukaryotic Microbiology 1996; 43:89S.

Bezuidenhout AJ, Penrith ML, Burger WP. Prolapse of the phallus and sewer in the ostrich (Strhutio came/us). Journal of South African Veterinary Association 1993; 64: 156-168.

Cama VA, Bern C, Sulaiman IM, Gilman RH, Ricona E, Vivar A, Kawai V, Vargas D, Zhou L, Xiao L. Cryptosporidium species and genotypes in HIV-positive patients in Lima, Peru. Journal of Eukaryotic Microbiology 2003; 50:531-533.

Current WL, Upton SJ, Haynes TB. The life cycle of Cryptosporidium baileyi n.sp. (Apicomplexa, Cryptosporididae) infecting chickens. Journal of Protozoology 1986; 33:289-296.

Egyed Z, Sréter T, Széll T, Bestzteri B, Dobos-kovács M, Márialigeti $\mathrm{K}$, Cornelissen AWCA, Varga I. Polyphasic typing of Cryptosporidium baileyi: the suggested model for characterization of cryptosporidia. Journal of Parasitology 2002; 88:237-243.

Elliot A, Morgan UM, Thompson RCA. Improved staining method for detecting Cryptosporidium oocysts in stools using malachite green. Journal of General and Applied Microbiology 1999; 45: 139-142.

Gajadhar AA. Cryptosporidium species in imported ostriches and consideration of possible implications for birds in Canada. Canadian Veterinary Journal 1993; 34:115-116.

Gajadhar AA. Host specificity studies and oocysts description of the Cryptosporidium sp. isolated from ostriches. Parasitology 1994; 80:316-319.
Gatei W, Greensill J, Ashford RW, Cuevas LE, Parry CM, Cunliffe NA, Beeching NJ, Hart CA. Molecular analysis of the 18S rRNA gene of Cryptosporidium parasites from patients with or without human immunodeficiency virus infections living in Kenya, Malawi, Brazil, the United Kingdom, and Vietnam. Journal of Clinical Microbiology 2003; 41:1458-1462.

Guyot K, Follet-Dumoulin A, Lelievre E, Sarfati C, Rabodonirina M, Nevez G, Cailliez JC, Camus D, Dei-Cas E. Molecular characterization of Cryptosporidium isolates obtained from humans in France. Journal of Clinical Microbiology 2001; 39:3472-3480.

Jardine JE, Verwoerd DJ. Pancreatic cryptosporidiosis in ostriches. Avian Pathology 1997; 26:665-670.

Lindsay DS, Blagburn BL, Sundermann, CA. Morphometric comparison of the oocysts of Cryptosporidium baileyi and Cryptosporidium meleagridis from birds. Proceedings of the Helminthological Society of Washington 1989; 56:91-92.

McLauchlin J, Amar C, Pedraza-Diaz S, Nichols GL. Molecular epidemiological analysis of Cryptosporidium spp. in the United Kingdom: results of genotyping Cryptosporidium spp. in 1,705 fecal samples from humans and 105 fecal samples from livestock animals. Journal of Clinical Microbiology 2000; 38:3984-3990.

Meireles MV, Figueiredo PC. Isolamento e identificação do Cryptosporidium baileyi, Current et al., (Apicomplexa: Cryptosporidiidae) em frangos de corte. Brazilian Journal of Veterinary Parasitology 1992; 1,2:125-130.

Meireles MV, Paulillo BC, Silva GS, Luvizotto MCR, Costa AJ, Andreatti Filho R L. Experimental infection with Cryptosporidium baileyi in floor-pen raised broilers. Brazilian Journal of Poultry Science 1999; 1:37-42.

Morgan U, Weber R, Xiao L, Sulaiman I, Thompson RC, Ndiritu W, Lal A, Moore A, Deplazes P. Molecular characterization of Cryptosporidium isolates obtained from human immunodeficiency virus-infected individuals living in Switzerland, Kenya, and the United States. Journal of Clinical Microbiology 2000; 38:11801183.

Morgan UM, Monis PT, Xiao L, Limor J, Sulaiman I, Raidal S, O'Donoghue P, Gasser R, Murray A, Fayer R, Blagburn BL, Lal AA, Thompsom RCA. Molecular and phylogenetic characterization of Cryptosporidium from birds. International Journal for Parasitology $2001 ; 31: 289-296$

Pedraza-Diaz S, Amar C, McLauchlin J. The identification and characterisation of an unusual genotype of Cryptosporidium from human faeces as Cryptosporidium meleagridis. FEMS Microbiology Letters 2000; 189:189-194.

Penrith ML, Burger WP. The Cryptosporidium sp. in an ostrich. Journal of South African Veterinary Association 1993; 64:60-61.

Penrith ML, Bezuidenhout AJ, Burger WP, Putterill JF. Evidence of cryptosporidial infection as a cause of prolapse of the phallus and cloaca in ostrich chicks (Struthio camelus). Onderstepoort Journal of Veterinary Research 1994; 61:283-289. 
Ryan UM, Monis P, Enemark HL, Sulaiman I, Samarasinghe B, Read C, Buddle R, Robertson I, Zhout L, Thompson RCA, Xiao L. Cryptosporidium suis $\mathrm{n}$. sp. (Apicomplexa: Cryptosporididae) in pigs (Sus Scrofa). Journal of Parasitology 2004; 90:769-773.

Ryan UM, Xiao L, Read C, Sulaiman IM, Monis P, Lal AA, Fayer R, Pavlasek I. The redescription of Cryptosporidium galli Pavlasek, 1999 (Apicomplexa: Cryptosporidiidae) from birds. Journal of Parasitology 2003; 89:809-813.

Slavin D. Cryptosporidium meleagridis (sp. nov.). Journal of Comparative Pathology 1955; 65:262-266.

Sréter T, Kovacs G, Silva AJ, Pienazek NJ, Szell Z, Dobos-Kovacs M, Marialigeti K, Varga I. Morphologic, host specificity, and molecular characterization of a Hungarian Cryptosporidium isolate. Applied and Environmental Microbiology 2000; 66:735-738.

Sréter T, Varga I. Cryptosporidiosis in birds - a review. Veterinary Parasitology 2000; 87:261-279.

Tiangtip R, Jongwutiwes, S. Molecular analysis of Cryptosporidium species isolated from HIV-infected patients in Thailand. Tropical Medicine and International Health 2002; 7:357-364.

Xiao L, Fayer R, Ryan U, Upton SJ. Cryptosporidium taxonomy: recent advances and implications for public health. Clinical and Microbiological Reviews 2004; 17:72-97.

Xiao L, Morgan UM, Limor J, Escalante A, Arrowood M, Shulaw W, Thompson RCA, Fayer R, Lal AA. Genetic diversity within Cryptosporidium parvum and related Cryptosporidium species. Applied and Environmental Microbiology 1999; 65:3386-3391. 